\title{
PENGARUH MANAJEMEN STRES TERHADAP PENURUNAN KADAR GULA DARAH PADA PENDERITA DIABETES MELLITUS DI DESA CINTA RAKYAT KECAMATAN PERCUT SEI TUAN KABUPATEN DELI SERDANG TAHUN 2020
}

\author{
Edisyah Putra Ritonga', Rizky Wahyu ningsih ${ }^{2}$ \\ ${ }^{I}$ Program Studi Profesi Ners, Universitas Imelda Medan, \\ Email: ${ }^{1}$ ediritonga87@gmail.com
}

\begin{abstract}
ABSTRAK
Diabetes Milletus merupakan keadaan kronis yang ditandai dengan peningkatan glukosa darah dan disertai dengan munculnya gejala utama yang spesifik, yaitu urin yang berasa manis dan dalam jumlah yang besar. Stres adalah respon tubuh yang tidak spesifik terhadap setiap kebutuhan yang terganggu, suatu fenomena universal yang terjadi dalam kehidupan sehari-hari dan tidak dapat dihindari, setiap orang mengalaminya, stres memberi dampak secara total pada individu yaitu terhadap fisik, psikologis, intelektual, sosial dan spiritual, stres dapat mengancam kesimbangan fisiologis. Jenis penelitian yang digunakan dalam penelitian ini adalah Kuantitatif dengan menggunakan desain penelitian Quasi eksperimental design dengan tipe One Group Pretest-Posttest Design. Populasi pada penelitian ini adalah warga dusun IX dan dusun X di Desa Cinta Rakyat, jumlah populasi pada penelitian ini adalah 30 orang penderita penyakit Diabetes Milletus. Besar sampel dalam penelitian ini adalah seluruh populasi yang di sesuaikan dengan kriteria berjumlah 30 orang penderita Diabetes Milletus. Data di analisis secara Univariat dan Bivariat menggunakan Uji Wilcoxon, menunjukkan nilai signifikan 0,002 yang berarti hipotesis diterima dan nilai $(\alpha=0,005)=0,002<0,005$. Diharapkan kepada Bagi para warga dan juga responden yang berada di Dusun IX dan X Desa Cinta Rakyat harus dapat melakukan terapi non farmakologi manajemen stres di rumah agar penyakit diabetes mellitus dapat dicegah.
\end{abstract}

Kata kunci : Diabetes Mellitus, Stres, Manajemen stres.

\section{ABSTRACT}

Milletus diabetes is an emergency in a condition that is concerned with increased blood and specific specific symptoms, namely urine that tastes sweet and in large quantities. Stress is the body's response that is not specific to every need that is not disturbed, a universal phenomenon that occurs in everyday life and cannot be avoided, every person who experiences it, stress has a total impact on the individual, namely physical, psychological, intellectual, social and spiritually, stress can threaten the physiological balance. The type of research used in this research is quantitative by using a quasi experimental research design with the type of One Group Pretest-Posttest Design. The population in this study were residents of hamlet IX and hamlet $X$ in Cinta Rakyat village, the total population in this study were 30 people with Diabetes Milletus disease. The sample size of this study is the entire population according to the criteria set in 30 people with Diabetes Milletus. Univariate and bivariate data analysis using the Wilcoxon Test. a significant value of 0.002 which means that it indicates acceptance and value $(\alpha=0.005)=0.002$ $<0.005$. It is expected that residents and also respondents in IX and X Dusun Cinta Rakyat Village must be able to carry out non-pharmacological stress management therapy at home so that diabetes mellitus can be prevented.

Keywords: Diabetes Mellitus, Stress, Stress Management

\section{PENDAHULUAN}

Diabetes Milletus merupakan keadaan kronis yang ditandai dengan peningkatan glukosa darah dan disertai dengan munculnya gejala utama yang spesifik, yaitu urin yang berasa manis dan dalam jumlah yang besar. Istilah diabetes berasal dari bahasa Yunani yang berarti "Siphon", yaitu ketika tubuh menjadi suatu saluran untuk mengeluarkan cairan yang berlebihan, dan "milletus" dari bahasa Yunani dan latin yang artinya madu. Kelainan yang menjadi penyebab dari diabetes milletus adalah defisiensi relative atau absolute dari hormon insulin. Insulin merupakan satu-satunya hormon yang dapat 
menurunkan kadar glukosa darah (Rudy \& Donelly Richard, 2014).

Terdapat dua jenis penyakit diabetes, yang pertama adalah diabetes tipe I dan diabetes tipe II. Diabetes tipe I atau yang disebut dengan Insulin Dependent Diabetes Melitus (IDDM) adalah jenis diabetes yang paling sering terjadi pada anak-anak dan dewasa muda, walaupun ini bisa terjadi juga pada usia berapapun (WHO, 1995; Leslie, 1991; Margatan, 2001). Penanganan untuk diabetes tipe I ini biasanya dengan memberikan suntikan insulin (Fisher dkk, 1982). Diabetes tipe yang kedua adalah Non Insulin Dependent Diabetes Mellitus (NIDDM). Diabetes tipe II ini biasanya terjadi pada orang-orang dewasa dan biasanya merupakan penyakit yang di turunkan (gen) (Margatan, 2001). Menurut (Fisher dkk, 1982) penyakit diabetes (terutama tipe II) juga sering muncul setelah seseorang berada pada usia di atas 40 tahun, terutama juga pada mereka yang memiliki kelebihan berat badan sehingga tubuhnya tidak peka lagi terhadap insulin (Jamaluddin \& Si, 2008).

Diabetes melittus tipe II adalah diabetes resisten insulin, pada penderita diabetes tipe II pankreas masih bisa membuat insulin, tetapi kualitasnya buruk.Banyak penderita tidak menyadari bahwa mereka telah mengidap diabetes, karena gejalanya memang perlahan sehingga tidak dirasakan. Penderita biasanya baru menyadari setelah mereka mengalami berbagai komplikasi dan didiagnosis oleh dokter mengalami diabetes (Mhd. Zainuddin, Wasisto Utomo, 2015).

Menurut data dari World Health Organization (WHO) jumlah penderita diabetes telah meningkat dari 108 juta pada tahun 1980 menjadi 422 juta pada tahun 2014. Tingkat penyebaran diabetes secara global di kalangan orang dewasa yang berusia diatas 18 tahun telah meningkat dari $(4,7 \%)$ pada tahun 1980 menjadi $(8,5 \%)$ pada tahun 2014. Jumlah penderita diabetes meningkat lebih cepat di negara-negara berpenghasilan menengah dan rendah. Diabetes adalah penyebab utama kebutaan, gagal ginjal, serangan jantung, stroke, dan amputasi anggota tubuh bagian bawah. Pada tahun 2016, di perkirakan bahwa 1,6 juta orang meninggal dunia akibat diabetes, 2,2 juta kematian lainnya di sebabkan oleh glukosa darah tinggi pada tahun 2012 .
Telah di prediksikan oleh World Health Organization (WHO) meningkatnya jumlah penderita diabetes yang cukup besar pada tahun-tahun yang akan datang. World Health Organization (WHO) memprediksi kenaikan jumlah penderita Diabetes Milletus di Indonesia dari 8,4 juta pada tahun 2000 menjadi sekitar 21,3 juta pada tahun 2030 . Internasional Diabetes Federation (IDF) juga mengemukakan hal yang sama dengan WHO tentang diabetes, pada tahun 2009 di prediksi jumlah penderita Diabetes Milletus dari 7,0 juta pada tahun 2009 meningkat menjadi 12,0 juta pada tahun 2030. Menurut WHO, saat ini Indonesia menempati urutan ke-4 terbesar dalam jumlah penderita Diabetes Milletus di dunia (Adam \& Tomayahu, 2019).

Prevalensi diabetes di Indonesia meningkat dari tahun ke tahun. Penderita yang terkena bukan hanya berusia lanjut, namun banyak pula yang masih berusia produktif. Prevalensi diabetes milletus berdasarkan diagnosis dokter dan gejala meningkat sesuai dengan bertambahnya umur, namun mulai umur $>65$ tahun cenderung menurun. Prevalensi diabetes milletus pada perempuan cenderung lebih tinggi dari pada laki-laki, di perkotaan cenderung lebih tinggi dari pada di perdesaan, serta cenderung lebih tinggi pada masyarakat dengan tingkat pendidikan tinggi (Riskerdas, 2013) (Elpriska, 2016).

Hasil dari Riset Kesehatan Dasar (Riskesdas) pada tahun 2013, menunjukkan bahwa hasil dari prevalensi diabetes, penduduk DI Yogyakarta menepati angka tertinggi yang mengalami diabetes di Indonesia sekitar $(2,6 \%)$ dari jumlah penduduk. Peringkat kedua yaitu kota DKI Jakarta sebanyak $(2,5 \%)$ dari jumlah pendduuk, di susul oleh Sulawesi Utara sebanyak $(2,4 \%)$ dari jumlah penduduk dan yang terakhir Kalimantan Timur sebanyak $(2,3 \%)$ dari jumlah penduduk. Sedangkan untuk prevalensi gejala diabetes yang terdiagnosis dokter, tertinggi terdapat di Sulawesi Tengah sebanyak (3,7\%) dari jumlah penduduk, kemudian Sulawesi Utara sebanyak $(3,6 \%)$ dari jumlah penduduk, Sulawesi Selatan sebanyak $(3,4 \%)$ dari jumlah penduduk dan Nusa Tenggara Timur sebanyak (3,3\%) dari jumlah penduduk (Adam \& Tomayahu, 2019). 
Menurut data yang diperoleh dari Survailans Terpadu Penyakit (STP) pada tahun 2008, jumlah kasus diabetes terlihat paling banyak terjadi, yaitu dengan jumlah kasus Diabetes Miletus mencapai 918 pasien yang ada di 123 rumah sakit di 28 kota atau kabupaten di seluruh provinsi Sumatera Utara, data dari Riskesdas (2013) jumlah prevalensi Diabetes Melitus yang telah didiagnosa oleh Nakes (tenaga kesehatan) dan disertai dengan gejala diperoleh data, yaitu untuk Samosir (0,3\%), Dairi (1\%), Serdang Bedagai $(0,6 \%)$, Tapanuli Utara $(0,3 \%)$, lalu jumlah prevalensi Diabetes Mellitus untuk kota Medan yaitu (2,7\%) dan jumlah prevalensi Diabetes Melitus untuk propinsi Sumatera Utara adalah (1,98\%), sementara data terakhir yang dikeluarkan oleh Depkes RI menyatakan prevalensi DM secara nasional adalah $(5,7 \%)$ (Bangun, 2018) .

Stres adalah respon tubuh yang tidak spesifik terhadap setiap kebutuhan yang terganggu, suatu fenomena universal yang terjadi dalam kehidupan sehari-hari dan tidak dapat dihindari, setiap orang mengalaminya, stres memberi dampak secara total pada individu yaitu terhadap fisik, psikologis, intelektual, sosial dan spiritual, stres dapat mengancam kesimbangan fisiologis (Meivy dkk, 2017) (Adam \& Tomayahu, 2019). Tingkat stres yang tinggi dapat memicu kadar gula darah seseorang semakin meningkat, sehingga semakin tinggi tingkat stres yang dialami oleh pasien Diabetes, maka penyakit Diabetes Melitus yang diderita akan semakin tambah buruk (Izzati \& Nirmala, 2015). Stres dan Diabetes Melitus memiliki hubungan yang sangat erat terutama pada penduduk perkotaan. Tekanan kehidupan dan gaya hidup tidak sehat sangat berpengaruh, ditambah dengan kemajuan teknologi yang semakin pesat dan berbagai penyakit yang sedang diderita menyebabkan penurunan kondisi seseorang sehingga memicu terjadinya stres (Meivy dkk, 2017) (Adam \& Tomayahu, 2019).

Dari hasil analisis stres didapatkan bahwa rata-rata skor stres 35,95 dengan standar deviasi (SD) 12,835. Skor stres minimal adalah 18 dan maksimal adalah 56. Berdasarkan hasil penelitian tingginya proporsi stres pada pasien diabetes melitus disebabkan karena perubahan psikologis sebagai dampak dari penyakit kronis yang dialami oleh pasien. Pasien yang terbebani oleh penyakitnya dan berfikir bahwa diabetes melitus adalah penyakit yang berat dan menakutkan, merupakan hal yang tidak menyenangkan dan dapat menimbulkkan stres (Pratiwi et al., 2014).

Menurut (Luthfi Nur Azhari, 2016) Manajemen stres dapat di definisikan sebagai intervensi yang dirancang untuk mengurangi efek dari stres. Berdasarkan penelitian yang dilakukan, manajemen stres yang baik dapat meningkatkan manajemen diri pada penderita diabetes milletus. Penelitian tersebut dilaksanakan dengan memberikan pelatihan manajemen stres meliputi mengenali emosi, mengenal stres dan sumber stres, strategi koping, dan berlatih teknik relaksasi (Azhari, 2016).

Selain itu banyak hal yang diperkirakan menjadi penyebab timbulnya stres diantaranya kurang pengetahuan akan penyakit yang diderita yaitu diabetes milletus secara rinci, kurangnya informasi mengenai diabetes milletus dari petugas kesehatan, kurang istirahat dan terlalu lelah karena aktifitas yang padat, kebisingan serta lingkungan yang tidak kondusif menjadi penyebab timbulnya stres pada pasien diabetes mellitus (Pratiwi et al., 2014).

Berdasarkan survey pendahuluan yang dilakukan oleh peneliti di Desa Cinta Rakyat Kecamatan Percut Sei Tuan Kabupaten Deli Serdang Tahun 2020 dengan melakukan wawancara langsung pada penderita, penderita diabetes milletus sebagian besar mengatakan bahwa penyakitnya sudah lama dialami dan tidak ada penurunan angka kadar gula darah yang signifikan. Maka dari itu peneliti tertarik untuk mengangkat kasus ini sehingga menjadi topik pembahasan dari judul penelitian ini.

\section{METODE}

Jenis penelitian yang digunakan dalam penelitian ini adalah Kuantitatif dengan menggunakan desain penelitian Quasi eksperimental design dengan tipe One Group Pretest-Posttest Design yang bertujuan untuk mengetahui pengaruh manajemen stres terhadap penurunan gula darah pada pasien diabetes. Penelitian ini tidak memiliki kontrol sebagai pembanding dari intervensi yang dilakukan. Penelitian ini dilakukan di Desa Cinta Rakyat Kecamatan Percut Sei Tuan 
Kabupaten Deli Serdang Provinsi Sumatera Utara.

Populasi pada penelitian ini adalah warga dusun IX dan dusun X di Desa Cinta Rakyat, jumlah populasi pada penelitian ini adalah 30 orang penderita penyakit Diabetes Milletus. Besar sampel dalam penelitian ini adalah seluruh populasi yang di sesuaikan dengan kriteria berjumlah 30 orang penderita Diabetes Milletus. Data di analisis secara Univariat dan Bivariat menggunakan Uji Wilcoxon, menunjukkan nilai signifikan 0,002 yang berarti hipotesis diterima dan nilai $(\alpha=0,005)=0,002<0,005$.

Adapun intervensi yang dilakukan dalam penelitian ini adalah dengan melakukan dan melatih pasien diabetes dalam manajemen stres yaitu: Melatih kesabaran pasien diabetes, Menganjurkan kepada penderita diabetes untuk selalu berhati hati dalam melakukan aktifitas sehari-hari, Menganjurkan kepada penderita diabetes untuk rekreasi baik secara mandiri maupun bersama dengan keluarga, Melatih teknik relaksasi nafas dalam, Berkolaborasi dengan keluarga, teman dan orang terdekat untuk memberi perhatian lebih kepada penderita diabetes. Untuk mengetahui apakah ada pengaruh dari intervensi manajemen stress yang diberikan terhadap penurunan kadar gula darah dengan melakukan pre test dan post test terhadap pemeriksaan gula darah yaitu pengukuran kadar gula darah sebelum dilakukan intervensi dan pengukuran kadar gula darah setelah dilakukan intervensi, analisa data dilakukan dengan menggunakan Wilcoxon Test, pada batas kemaknaan perhitungan statistik $\mathrm{P}$ value $(0,005)$.

\section{HASIL DAN PEMBAHASAN}

3.1 Hasil

Tabel 1. Distribusi Frekuensi Berdasarkan Jenis Kelamin Penderita Diabetes Mellitus

\begin{tabular}{cccc}
\hline No & $\begin{array}{c}\text { Jenis } \\
\text { Kelamin }\end{array}$ & $\begin{array}{c}\text { Frekuensi } \\
\text { (jumlah) }\end{array}$ & $\begin{array}{c}\text { Persentasi } \\
(\mathbf{\%})\end{array}$ \\
\hline 1 & Laki - laki & 13 & 43,3 \\
\hline 2 & Perempuan & 17 & 56,7 \\
\hline & Total & $\mathbf{3 0}$ & $\mathbf{1 0 0}$ \\
\hline
\end{tabular}

Berdasarkan tabel 1 diketahui bahwa berdasarkan jenis kelamin mayoritas responden berjenis kelamin perempuan yaitu sebanyak 17 orang $(56,7 \%)$, minoritas responden berjenis kelamin laki laki yaitu sebanyak 13 orang $(43,3 \%)$.
Tabel 2. Karakteristik Responden

Berdasarkan Distribusi Frekuensi Usia Penderita Diabetes Mellitus

\begin{tabular}{cccc}
\hline No & $\begin{array}{c}\text { Usia } \\
\text { (Tahun) }\end{array}$ & $\begin{array}{c}\text { Frekuensi } \\
\text { (Jumlah) }\end{array}$ & $\begin{array}{c}\text { Persentasi } \\
(\boldsymbol{\%})\end{array}$ \\
\hline 1 & $35-40$ & 7 & 23,3 \\
\hline 2 & $41-45$ & 11 & 36,7 \\
\hline 3 & $46-50$ & 12 & 40 \\
\hline & Total & $\mathbf{3 0}$ & $\mathbf{1 0 0}$ \\
\hline
\end{tabular}

Berdasarkan tabel 2, diketahui bahwa berdasarkan distribusi frekuensi usia responden, mayoritas responden yang interval usianya 55-60 tahun sebanyak 12 orang (40\%), sedangkan minoritas responden yang interval usianya 35-40 tahun sebanyak 7 orang $(23,3 \%)$.

Tabel 3. Karakteristik Responden Berdasarkan Distribusi Frekuensi Pekerjaan Penderita Diabetes Mellitus

\begin{tabular}{clcc}
\hline No & Pekerjaan & $\begin{array}{c}\text { Frekuensi } \\
\text { (Jumlah) }\end{array}$ & $\begin{array}{c}\text { Persentasi } \\
(\mathbf{\%})\end{array}$ \\
\hline 1 & Petani & 6 & 20 \\
\hline 2 & $\begin{array}{l}\text { Ibu Rumah } \\
\text { Tangga }\end{array}$ & 9 & 30 \\
\hline 3 & Wiraswasta & 5 & 16,7 \\
\hline 4 & PNS & 4 & 13,3 \\
\hline 5 & Nelayan & 6 & 20 \\
\hline & Total & $\mathbf{3 0}$ & $\mathbf{1 0 0}$ \\
\hline
\end{tabular}

Berdasarkan tabel 3 diatas, diketahui bahwa berdasarkan distribusi frekuensi pekerjaan responden, mayoritas responden berdasarkan pekerjaan Ibu Rumah Tangga sebanyak 9 orang $(30 \%)$, sedangkan minoritas responden berdasarkan pekerjaan PNS sebanyak 4 orang $(13,3 \%)$

\section{Tingkat Stres}

Berdasarkan penelitian, tingkat stres pada penderita diabetes mellitus dapat dilihat pada tabel dibawah ini.

Tabel 4. Distribusi Frekuensi Responden Berdasarkan Pre Tingkat Stres pada Penderita Diabetes Mellitus

\begin{tabular}{clcc}
\hline No & Tingkat Stres & $\begin{array}{c}\text { Frekuensi } \\
\text { (jumlah) }\end{array}$ & $\begin{array}{c}\text { Persentasi } \\
(\mathbf{\%})\end{array}$ \\
\hline 1 & Ringan & 9 & 30 \\
\hline 2 & Sedang & 13 & 43,3 \\
\hline 3 & Berat & 8 & 26,7 \\
\hline & Total & $\mathbf{3 0}$ & $\mathbf{1 0 0}$ \\
\hline
\end{tabular}

Berdasarkan tabel 4 diatas, diketahui bahwa responden yang mengalami stres ringan sebelum di berikan manajemen stres sebanyak 9 orang $(30 \%)$, stres sedang sebelum di berikan manajemen stres sebanyak 13 orang $(43,3 \%)$ dan stres berat 
sebelum di berikan manajemen stres sebanyak 8 orang $(26,7 \%)$.

Tabel 5. Distribusi Frekuensi Responden Berdasarkan Post Tingkat Stres pada Penderita Diabetes Mellitus

\begin{tabular}{cccc}
\hline No & $\begin{array}{c}\text { Tingkat } \\
\text { Stres }\end{array}$ & $\begin{array}{c}\text { Frekuensi } \\
\text { (jumlah) }\end{array}$ & $\begin{array}{c}\text { Persentasi } \\
(\mathbf{\%})\end{array}$ \\
\hline 1 & Ringan & 21 & 70 \\
\hline 2 & Sedang & 6 & 20 \\
\hline 3 & Berat & 3 & 10 \\
\hline & Total & 30 & 100 \\
\hline
\end{tabular}

Berdasarkan tabel 5 diatas, diketahui bahwa responden yang mengalami stres ringan setelah di berikan manajemen stres sebanyak 21 orang $(70 \%)$, stres sedang setelah di berikan manajemen stres sebanyak 6 orang $(20 \%)$ dan stres berat setelah di berikan manajemen stres sebanyak 3 orang $(10 \%)$.

\section{Kadar Gula Darah}

Tabel 6. Distribusi Frekuensi Responden Berdasarkan Kadar Gula Darah Penderita Diabetes Mellitus Sebelum (Pre test) di berikan Manajemen Stres

\begin{tabular}{cc|cc}
\hline No & Nilai KGD & $\begin{array}{c}\text { Frekuensi } \\
\text { (jumlah) }\end{array}$ & $\begin{array}{c}\text { Persentasi } \\
(\boldsymbol{\%})\end{array}$ \\
\hline 1 & Tinggi $>200$ & 21 & 70 \\
\hline 2 & Rendah $<200$ & 9 & 30 \\
\hline & Total & 30 & 100 \\
\hline
\end{tabular}

Tabel 7. Distribusi Frekuensi Responden Berdasarkan Kadar Gula Darah Penderita

Diabetes Mellitus Sesudah Post test di berikan Manajemen Stres

\begin{tabular}{cccc}
\hline No & Nilai KGD & $\begin{array}{c}\text { Frekuensi } \\
\text { (jumlah) }\end{array}$ & $\begin{array}{c}\text { Persentasi } \\
(\boldsymbol{\%})\end{array}$ \\
\hline 1 & Tinggi $>200$ & 10 & 33,3 \\
\hline 2 & Rendah $<200$ & 20 & 66,7 \\
\hline & Total & 30 & 100 \\
\hline
\end{tabular}

Berdasarkan tabel diatas dapat dilihat kadar gula darah sebelum dilakukan manajemen stres pada penderita diabetes mellitus dengan kadar gula darah tinggi sebanyak 21 orang $(70 \%)$, sedangkan kadar gula darah rendah sebanyak 9 orang (30\%). Sedangkan sesudah di lakukan manajemen stres pada penderita diabetes mellitus dengan kadar gula darah tinggi sebanyak 10 orang $(33,3 \%)$ dan kadar gula darah rendah sebanyak $20(66,7 \%)$.

Pada penelitian ini data yang diperoleh dapat dianalisa dengan analisis bivariat yaitu untuk mengetahui pengaruh manajemen stres terhadap kadar gula darah pada penderita diabetes mellitus di Dusun IX dan X Desa Cinta Rakyat Kecamatan Percut Sei Tuan Kabupaten Deli Serdang dapat dilihat pada tabel hasil uji Wilcoxon di bawah ini:

Tabel 8. Hasil Uji Wilcoxon

\begin{tabular}{llrrr}
\hline No & \multicolumn{1}{c}{ Variabel } & $\begin{array}{c}\text { Jumlah } \\
(\mathbf{n})\end{array}$ & Mean & $\begin{array}{c}\text { P. } \\
\text { value }\end{array}$ \\
\hline 1 & Sebelum (pre-test) & 30 & 7,00 & 0,002 \\
\hline 2 & Sesudah (post-test) & 30 & 7,00 & \\
\hline & Ket: $\quad$ Berdasarkan & tabel & diatas
\end{tabular}
menunjukkan nilai signifikan 0,002 yang berarti hipotesis diterima dan nilai $(\alpha$ $=0,005)=0,002<0,005$, yang dimana adanya pengaruh pemberian manajemen stres terhadap penderita diabetes mellitus $\mathrm{P}<0,005$ maka ada pengaruh manajemen stres terhadap kadar gula darah pada penderita diabetes mellitus sebelum dengan sesudah.

\subsection{Pembahasan}

Pengaruh Manajemen Stres Terhadap Kadar Gula Darah Penderita Diabetes Mellitus Sebelum Dan Sesudah Dilakukan Manajemen Stres

Hasil penelitian berdasarkan nilai kadar gula darah responden sebelum dilakukan manajemen stres adalah sebagai berikut: kategori tinggi $>200$ sebanyak 21 orang (70\%), kategori rendah <200 sebanyak 9 orang (30\%). Dan hasil penelitian berdasarkan nilai kadar gula darah responden sesudah di lakukan manajemen stres adalah: Tinggi >200 sebanyak 10 orang $(33,3 \%)$, Rendah $<200$ sebanyak 20 orang $(66,7 \%)$. Dengan demikian untuk mengatasi stres penderita diabetes salah satunya adalah dengan memberikan manajemen stres sebagai salah satu tercapainya tujuan dari penelitian ini.

Hasil penelitian menunjukkan bahwa intervensi mengalami penurunan kadar gula darah. Berdasarkan hasil uji statistik dengan menggunakan uji wilcoxon test didapatkan nilai $p$ value sebesar $0,002 p<0,005$ yang artinya peneliti dalam pemberian manajemen stres terhadap nilai kadar gula darah pada penderita diabetes mellitus berpengaruh.Pada hasil ini peneliti dapat mengartikan hasil dari bantuan SPSS bahwa semakin sering manajemen stres yang diberikan kepada penderita diabetes maka kadar gula darah akan semakin turun. 
Berdasarkan hasil penelitian Luthfi Nur Azhari, 2016 tentang manajemen stres dapat di definisikan sebagai intervensi yang dirancang untuk mengurangi efek dari stres. Berdasarkan penelitian yang dilakukan, manajemen stres yang baik dapat meningkatkan manajemen diri dan penurunan kadar glukosa darah pada penderita diabetes milletus. Penelitian tersebut dilaksanakan dengan memberikan pelatihan manajemen stres meliputi mengenali emosi, mengenal stres dan sumber stres, strategi koping, dan berlatih teknik relaksasi (Azhari, 2016).

\section{KESIMPULAN}

Berdasarkan dari hasil penelitian dan pembahasan, maka peneliti dapat menyimpulkan sebagai berikut:

1. Kadar gula darah sebelum dilakukan intervensi nonfarmakologi manajemen stres kepada 30 responden di Desa cinta rakyat mengalami kenaikan dan tidak terkontrol.

2. Kadar gula darah sesudah dilakukan intervensi nonfarmakologi manajemen stres kepada 30 responden di Desa cinta rakyat mengalami penurunan yang signifikan dan mudah terkontrol.

3. Skala stres yang dialami penderita diabetes sebelum di lakukan intervensi non farmakologi manajemen stres adalah skala berat dan hampir mengganggu psikologi penderita.

4. Skala stres yang dialami penderita diabetes sesudah di lakukan intervensi non farmakologi manajemen stres adalah berskala ringan.

5. Ada pengaruh pemberian manajemen stres terhadap kadar gula darah pada penderita diabetes mellitus. Hasil dari uji wilcoxon menunjukkan besar nilai signifikansi $(p)$ sebesar 0,002. nilai signifikasin yang besarnya dibawah 0,005 mengindikasikan adanya pengaruh yang signifikan antara variabel pemberian manajemen stres terhadap kadar gula darah penderita diabetes mellitus.

\section{REFERENCES}

Adam, L., \& Tomayahu, M. B. (2019). Tingkat Stres Dengan Kadar Gula Darah. Journal Health and Sport, 1(1), 1-5.

Azhari, L. N. (2016). Manajemen Stress Pasien Dengan Ulkus Kaki Diabetikum
Di Rsud Kota Semarang. Technology, 1(1), 1-17.

Bangun, H. A. (2018). Hubungan Antara Kejadian Diabetes Melitus Pada Suami Dengan Kualitas Hubungan Biologis Suami Istri Di Kelurahan Perdamean Kecamatan Rantau Selatan Kabupaten Labuhanbatu Tahun 2018. Kesehatan Masyarakat Dan Lingkungan Hidup, 1, 43.

Elpriska. (2016). Pengaruh Stres, Dukungan Keluarga dan Manajemen Diri Terhadap Komplikasi Ulkus Kaki Diabetik Pada Penderita DM Tipe 2 Influences Of Stress, Family Support, And Self Management Toward Complication Of Diabetic Foot Ulcer Of Diabetes Mellitus Type 2 Patiens. Idea Nursing Journal, VII(1), 20-25.

Jamaluddin, M., \& Si, M. (2008). Strategi Coping Stres Penderita Diabetes Mellitus Dengan Self Monitoring Sebagai Variabel Mediasi. ElQUDWAH, O(0), 1-19.

Mhd. Zainuddin, Wasisto Utomo, H. (2015). Hubungan Stres Dengan Kualitas Hidup Penderita Diabetes Mellitus Tipe 2. 2(1). Pratiwi, P., Amatiria, G., \& Yamin, M. (2014). Pengaruh Stress Terhadap Kadar Gula Darah Sewaktu Pada Pasien Diabetes Melitus. Jurnal Kesehatan, 5(1), 11-16.

Rudy, B., \& Donelly Richard. (2014). BUKU PEGANGAN DIABETES (S. K. Ns. Barrarah Bariid (ed.); 4th ed.). Bumi Medika.

Berkat, Lintang Dian Saraswati, M. M. (2018). Faktor-Faktor Yang Berhubungan Dengan Kadar Gula Darah Pada Penderita Diabetes Melitus Tipe 2 Di Rsud K.R.M.T Wongsonegoro Semarang. Jurnal Kesehatan Masyarakat (e-Journal), 6(1), 200-206.

Bruce, 2011. (2013). Perbedaan Tingkat Stres dan Tingkat Insomnia yang Berasal dari Semarang dan Non Semarang di Fakultas Kedokteran Universitas Diponegoro. Journal of Chemical Information and Modeling, 53(9), 16891699. https://doi.org/10.1017/CBO978110741 5324.004

Donsu, J. D. T. (2019). PSIKOLOGI KEPERAWATAN (Tim Pustaka Baru (ed.); 1st ed.). PT. PUSTAKA BARU. 
Setadi. (2013). Konsep Dan Praktik 22(1), $31-42$. Penulisan Riset Keperawatan (2nd ed). Jakarta: Graha Ilmu.

Imelda, S. I. (2019). Faktor-Faktor Yang Mempengaruhi Terjadinya diabetes Melitus di Puskesmas Harapan Raya Tahun 2018. Scientia Journal, 8(1), 2839. https://doi.org/10.35141/scj.v8i1.406

Kusnanto, K., Sundari, P. M., Asmoro, C. P., \& Arifin, H. (2019). Hubungan Tingkat Pengetahuan Dan Diabetes SelfManagement Dengan Tingkat Stres Pasien Diabetes Melitus Yang Menjalani https://doi.org/10.7454/jki.v22i1.780

PH, L., Sari, I. P., \& Hermanto, H. (2018). Gambaran Tingkat Stres Pasien Diabetes Mellitus. Jurnal Perawat Indonesia, 2(1), https://doi.org/10.32584/jpi.v2i1.40

Tigauw, J. H., Kapantow, N. H., \& Sondakh, R. C. (2014). Hubungan antara Jenis Kelamin dengan kadar Adiponektin pada Penderita Diabetes Melitus Tipe 2 di Kota Manado. Fkm Unsrat, 1, 1-7.

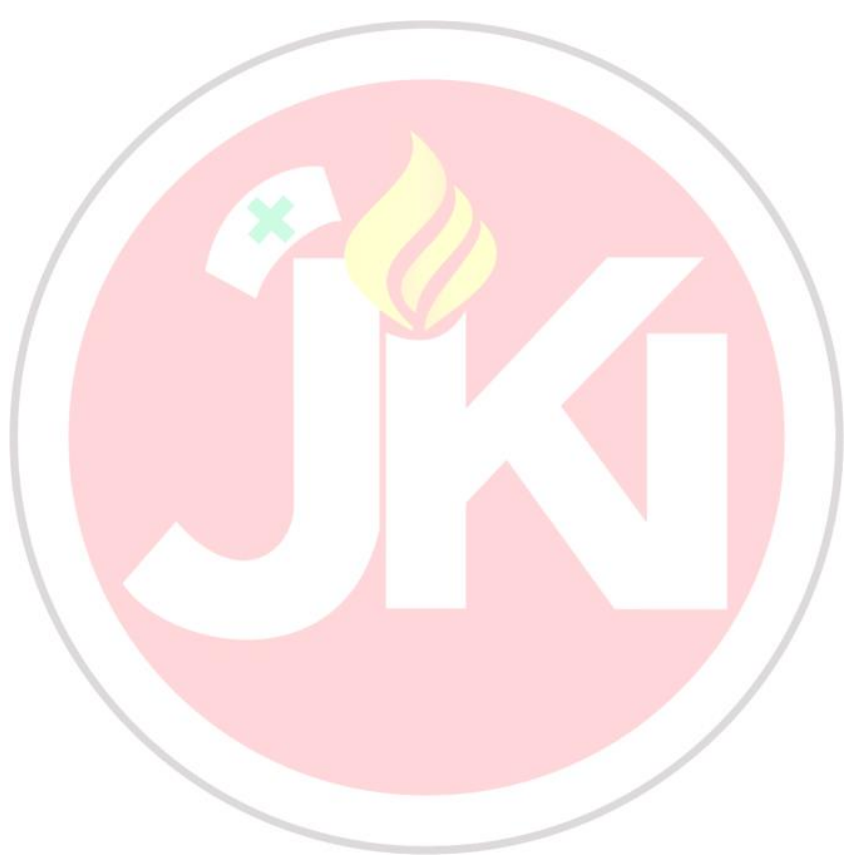

